\title{
The Role of Accounting in the Municipal Performance: An Empirical Study in the Central Region of Portugal
}

\author{
Maria da Conceição da Costa Marques ${ }^{1} \&$ José Ferreira Marques $^{2}$ \\ ${ }^{1}$ ISCAC, Higher Institute of Accounting and Administration of Coimbra, Portugal \\ ${ }^{2}$ Accounting and Business Taxation - Higher Institute of Accounting and Administration of Coimbra, Portugal \\ Correspondence: Maria da Conceição da Costa Marques, ISCAC, Higher Institute of Accounting and \\ Administration of Coimbra, Portugal. E-mail: mmarques@iscac.pt; conceicao.m@netcabo.pt
}

Received: March 21, 2014 Accepted: April 1, 2014 Online Published: October 18, 2014

doi:10.5539/par.v3n2p44 URL: http://dx.doi.org/10.5539/par.v3n2p44

\begin{abstract}
This article examines the differences in the adoption and implementation of the reform of financial accounting in the Portuguese municipalities. This study is based on a questionnaire sent to the financial officers of the Portuguese municipalities of Central Region of Statistics of Portugal, who had previously adopted the double entry accounting based on Official Accounting Plan of Local Authorities (POCAL). The questionnaire was structured in the same way for the whole target population. This study will be possible to verify, based on the responses obtained, if local authorities do what they are legally defined to do in the provision of financial information on the allocation of resources as well as on the development of performance indicators, based on accounting data.
\end{abstract}

Keywords: municipality, public accounting, indicator, performance, economy, efficiency and effectiveness

\section{Introduction}

\subsection{Introduce the Problem}

The accrual accounting in the public sector has attracted great interest from researchers and academics. This approach was developed based on the idea that one way to modernize public sector management will be adopting similar accounting practices to the private sector.

Since the 1990s some people have claimed that users of financial reporting in the public sector need complete and detailed financial information on the value of assets, liabilities, depreciation and net income. It is argued that this information is needed to determine the full cost of providing public goods and services and better evaluate the performance of politicians and managers.

This article examines the differences on the adoption and implementation of the reform of financial accounting in the Portuguese municipalities. This study is based on a questionnaire sent to the financial officers of the Portuguese municipalities in the Central Region of Portugal, who had previously adopted the double entry accounting based on POCAL. The questionnaire was structured in the same way for the whole target population.

With this study will be possible to verify, based on the responses obtained, if local authorities do what is legally defined about the provision of financial information on the allocation of resources as well as on the development of performance indicators, based the accounting data.

\subsection{Characterization of Portuguese Municipalities}

The Local Government corresponds to the activity carried out by local authorities. These are territorial legal persons, with representative bodies that seek to pursue specific interests of citizens in their area (part of the national territory).

In truth, there is no place to set local authority if it is not administered by the representative of the populations that comprise organs. It is through elections that are chosen representatives of the citizens that will protect and direct the policies for the various administrative bodies of local governments. Of all the political-strategic management performed by responsible, result in greater or lesser developments of its territorial space.

There are three types of local authorities in Portuguese territory, as shown in the table below: 
Table 1. Administrative organs of local authorities

\begin{tabular}{ccc}
\hline FREGUESIA & MUNICIPALITY & ADMINISTRATIVE REGION \\
\hline Parish Assembly & Municipal Assembly & Regional Assembly \\
& Municipality & Regional Board \\
Parish & Municipal Board & City Council \\
\hline
\end{tabular}

Source: Adapted Bilhim (2004:15)

Local authorities are territorial legal persons with representative bodies, to pursuit the own interests of respective populations (Article 235 of the PRC; Articles 1 and 2 of Decree-Law No. 100/84 of 29 March). Are traditionally designated by the City Council, have administrative and financial autonomy to manage the territorial space, designated "county", but that the 1976 Constitution enshrined as Municipality.

The strength of free peoples is in the Municipality "(...) without local institutions a nation may have a free government, but will lack the spirit of freedom (Alexis de Tocqueville: 1856)".

The supra-local authority is designated district, although it can admit its abolition and replacement by a broader supra-local authority designated by administrative region, that still remains elusive and is only been formally established in the CRP.

The Parishes are authorities of lower position, i.e. they are local authorities, within the municipality, to pursuit the self-interest of the resident population in each parish constituency.

In the creation, modification and termination of municipalities, the National Assembly should always take into account:

- The will of the populations concerned;

- Reasons of historical and cultural factors;

- Geographic, demographic, economic, social, cultural and administrative factors;

- Interests of national and regional or local, which might be concerned.

The Municipal Assembly is a deliberative body, while the City Council and Mayor are executive bodies.

The Administrative Region shall be, in accordance with Article 1 of Law No 56/ 91 of August 13, a territorial collective person, endowed with administrative and financial autonomy and representative bodies, to the pursuit of self-interest of the respective populations, as factor of social cohesion. Their representative bodies are the Regional Assembly and the Regional Council. The administrative and financial autonomy of administrative regions is based on the principle of subsidiarity in relation functions of the State and the municipalities and the unitary state organization.

Currently there are 308 municipalities in Portugal, which support the study published in the Annual Financial Report of Portuguese Municipalities (AFMP) 2009, grouped according to the authors in three different categories and with reference to size and number of inhabitants:

- Small - with a population less than or equal to 20,000 inhabitants;

- Medium - with a population greater than 20,000 and less than or equal to 100.000 inhabitants;

- Large - with more than 1,000,000 inhabitants.

According to this classification the numbers of Portuguese municipalities have thus ordered:

Table 2. Distribution of municipalities by category 2009

\begin{tabular}{|c|c|c|c|}
\hline Small & \multirow{2}{*}{\multicolumn{2}{|c|}{$\begin{array}{l}\text { Medium } \\
105\end{array}$}} & Large \\
\hline 180 & & & 23 \\
\hline $\begin{array}{c}500 \text { Inhabitants } \\
\text { (Corvo) }\end{array}$ & 20.000 Inhabitants & 100.000 Inhabitants & $\begin{array}{c}\text { 479,884 Inhabitants } \\
\text { (Lisbon) }\end{array}$ \\
\hline
\end{tabular}

Source: Adapted Carvalho et al (2009:20) 
In Madeira, the percentage is $64 \%$, i.e. 7 in 11 municipalities are small. Accompanied by the Azores where the percentage is $79 \%$, i.e. 15 in 19 as well as in the southern region of Portugal continental with $76 \%$, i.e. 45 in 59 are in the same order of magnitude. In contrast, in the Lisbon regions and Tagus Valley, the values go down in proportion to $39 \%$, i.e., 26 in 66 and $50 \%, 34$ in 68 , respectively. It is in the central region that the levels are to rise to $62 \%$, where 53 of the 85 municipalities are small.

Regarding the data presented for 2009, in this regard and according to the AFMP for the year 2010, no significant changes have emerged.

Table 3. Distribution of municipalities by category 2010

\begin{tabular}{|c|c|c|c|}
\hline Small & \multicolumn{2}{|c|}{ Medium } & Large \\
\hline 179 & & 23 \\
\hline $\begin{array}{l}507 \text { Inhabitants } \\
\text { (Corvo) }\end{array}$ & 20.000 Inhabitants & 100.000 Inhabitants & $\begin{array}{c}\text { 469,509 Inhabitants } \\
\text { (Lisbon) }\end{array}$ \\
\hline
\end{tabular}

Source: Adapted Carvalho et al (2009:22) AFMP 2010

\section{The Local Public Sector}

\subsection{Framework}

Made an analysis of the percentage weight of the subsectors allows us to compare their relative contribution to total public expenditure of the administrative sector, highlighting however the vertical structure of government financial activity (Note 1).

In Table 4 we observe expenditure of Central Government and Local Government and the total expenditure of the Public Sector Administrative (SPA) in 2009 and distributed in current and capital.

Table 4. Weight of municipal public expenditure 2009 (Unit: millions of euros)

\begin{tabular}{|c|c|c|c|c|c|c|}
\hline Subsector Expenses & \multicolumn{2}{|c|}{ Current \% } & \multicolumn{2}{|c|}{ Capital \% } & \multicolumn{2}{|c|}{ Total \% } \\
\hline Central Administration & $49.670,6$ & & $4.955,0$ & & $54.625,6$ & \\
\hline Local Government & $7.991,2$ & $10.3 \%$ & $3.021,6$ & $46.6 \%$ & $11.012,7$ & $13.1 \%$ \\
\hline TOTAL SPA & $77.049,9$ & & $6.481,4$ & & $83.531,3$ & \\
\hline
\end{tabular}

Source: Adapted from the General State Accounts 2009

As can be seen, the costs of local government amounted to in 2009 , about $13.1 \%$ of total expenditure, having this value reached in the previous three years, about $12.7 \%$.

In capital spending, which include gross fixed capital formation, the percentage was around $46.6 \%$, reflecting a high contribution of municipalities in public sector investment. We assume some relevance for comparison through the Figure 1, the values for Portugal and those relating to the EU average for the same period.

As we can see the weight of public expenditure in GDP in the period 2008-2012, is usually less than both the EU average or the Eurozone (with the exception of the year 2010).

\begin{tabular}{lrrrrr}
\hline & 2008 & 2009 & 2010 & 2011 & 2012 \\
\hline EU (27 countries) & 47 & 51 & 50,6 & 49,1 & 49,3 \\
Euro area (17 countries) & 47,1 & 51,2 & 51 & 49,5 & 49,9 \\
Portugal & 44,8 & 49,8 & 51,5 & 49,3 & 47,4 \\
\hline
\end{tabular}

Source: Eurostat Government statistics (2012)

Or, through chart: 


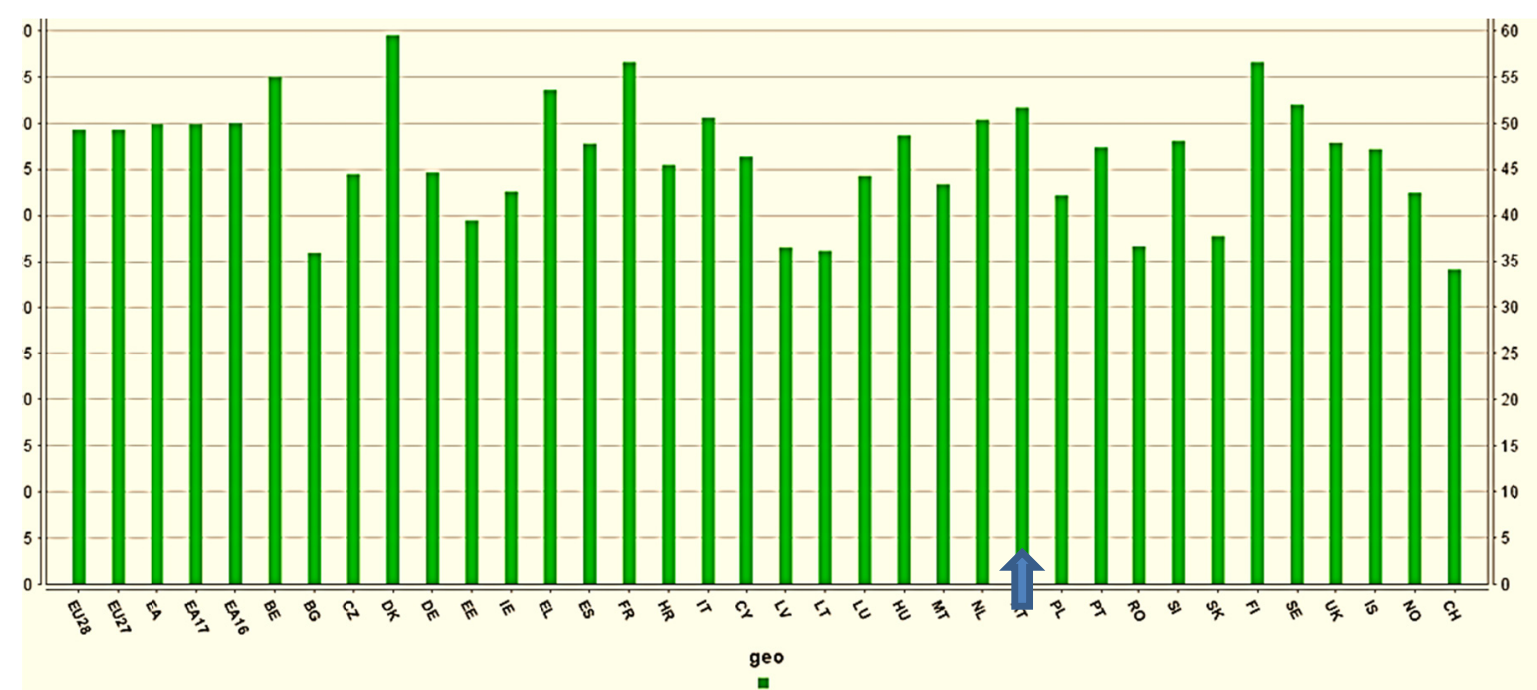

Figure 1. Total general government expenditure $\%$ of GDP

What is relevant from the point of view of validation of the Portuguese government accounts is the overall balance of the general government that, in general, corresponds to the SPA. This need for comprehensive financial analysis of the public sector was enshrined in the first amendment to the current law for the budget (LEO) (Law No. 91/2001 of 20 August). This change was due to changes introduced by the Budgetary Stability Law (Law No. 2/2002 of 28 August). Thus, LEO part V became a Party for the purpose of (...) "fulfill its obligations under article $104^{\circ}$ of the Treaty establishing the European Community and the Stability and Growth" (No. 2 Article $82^{\circ}$ of LEO). The scope has become of the entire SPA, including local authorities (Art. $83^{\circ}$ of the LEO).

\subsection{Duties and Powers of Portuguese Municipalities}

The CRP provides in Article 237 paragraph 1 that:

"( ... ) The functions and organization of local authorities, and the competence of its organs shall be regulated by law in accordance with the principle of administrative decentralization, then committing the budgetary powers of nature to representative assemblies of local authorities."

According to Article 13 of Law 159/99 of 14 September, updated, are skills of Portuguese municipalities' assignments in the following areas that relate to themselves, common and specific populations interests where they operate:

- Equipment rural and urban;

- Energy;

- Transport and communications;

- Education;

- Heritage, Culture and Science;

- Free time and sport;

- Health;

- Social Action;

- Housing;

- Civil Protection;

- Setting to sanitation;

- Consumer;

- Promoting the development;

- Spatial planning and urban design; 
- Municipal Police;

- External Cooperation.

The municipality may, by means of delegated powers and by protocol, transferring inserted tasks within their assignments to parishes that are part of the municipal territory under its jurisdiction.

\subsection{Accounting and Finance of Municipalities}

The changes, though slow, has been progressing mainly at the level of municipalities, by means of a more comprehensive reform of financial management and public accounting. The Reform of the Financial Administration of the State (RAFE) started in Portugal in the 1990s with the publication of the Law on Public Accounts (Law no. 8/90) followed by the publication of a series of laws that support current reforms. The set of legal documents highlight the publication in 1997 of the Official Plan of Public Accounting (POCP) approved by Decree-Law No. 232/97 dated September 3, applied to the entire public administration.

All this resulted from the demands that were placed on the public accounts and the need to develop and produce a variety of information, according to the particular purpose intended by the users, who increasingly demand more and better information for their decision making.

The quality of financial information provided in the reports and financial statements must religiously adhere to the following features:

- Relevance;

- Reliability;

- Comparability.

The relevance for the sustainable capacity in the quality of information that enables decision-makers to influence the intended audience, helping them evaluate past, present and future events or to confirm or correct your reviews.

Reliability is supported by quality information has to be free from material error and prejudge, to properly show what is intended to present or reasonably expected to submit and may therefore depend on it users .

Finally, the comparability of information which is based on the need of organizations adopts standardization of accounting systems, in order to facilitate comparability between these organizations. Therefore, disclosure and quantification of the financial effects of transactions and other events should be recorded consistently by the entity and over time, enabling the identification of trends.

\subsection{The Official Plan of Public Accounting (POCP)}

The POCP is essentially characterized as a method for applying the double-entry accounting for registration and gathered all three systems of accounting: financial, budgetary and analytical, as mentioned in the preamble to the regulatory analysis:

"( ... ) The creation of conditions for the integration of different aspects: financial accounting, budgetary and analytical, in a modern public accounting, which constitutes a key instrument to support the management of public entities and their evaluation."

This plan sets out a framework that accounts simultaneously coexist at the same level, the three accounting information systems: (a) budget (class 0 - accounts of budgetary control and order), (b) equity (classes 1-8); and (c) analytical (Class 9).

Carvalho (1999:184) argues that, with this accounting system, the classic goals are undermined to the detriment of other more important for making decisions: "(...) the classics objectives and other related to the usefulness information for decision-making by different users."

Still, according to Carvalho and Jorge (2003 and 2005), "(...) The POCP emerges as the key tool for reporting financial information and no longer only in the legal compliance, i.e., pass to permit also the analysis of the economic and financial situation of public entities."

As stated, this accounting system includes three accounting aspects: budgetary, financial and analytical aspects, only a single system, although each subsystem operates independently, also allowing for the consolidation of information for managers and policy makers.

Citing Barbosa (1994 ) "(...) allows for greater financial control by the different entities involved and providing information to different stakeholders in order to enhance transparency in public administration, namely, making the monitoring of budget execution in perspective of cash and commitments." 
Under the AECA, (2003:180) the basis of the increase is defined as:

"(...) the temporal allocation of costs and revenues should be done by the actual chain of goods and services and not when the resulting monetary or financial flow derived from the same occurs."

Despite the budgetary accounts be prepared on a cash basis, it appears that the principle of specialization (or increase) of POCP is very similar to the POC conceptual basis. As the main sources in drawing up the POCP were the POC and the General Plan of Spanish Public Accounting (PGCP), i.e., it was introduced as indeed refers Caiado (1997:158) to prevail in public accounting systems the rule that:

"(...) the costs and revenues (such as in private business reality) arising from the implementation of the budget will be imputed in accordance with the procedure laid down in each case."

"(...) If you can't clearly identify the actual flow of goods and services will be appreciated that the expenditure or revenue is produced when increments recognize the rights or obligations, or valuation corrections affecting the heritage elements".

\subsection{The Official Plan of Accounts for Local Authorities}

The evolution of accounting in Local Government has contributed in its fullness for improving budgetary, accounting techniques and the creation of new models of assessment, evidencing, given the scarcity of public resources and the social nature of these institutions, the need for disseminating them to arrange the evaluation indicators of financial, economic, equity and fiscal management of these local bodies.

The comparability of the performance came at the same time allow verifying the optimization of human and material resources, through the parameters of efficiency, effectiveness and quality of services provided by residents.

From what was previously said about the POCP, and its application to public administration, are considerable and very important innovation, which will be transported to the accounts of local authorities. Over the next two years with the publication of Decree-Law no. 54-A/99 (Note 2) of February 22, the new accounting system was approved by local authorities, as amended by Law No. 162/ 99 of 14 September and Decree-Law No. 315/2000, of December 2, entering into force on 1 January, 2002.

As a corollary of this reform process, the Official Accounting Plan of Local Authorities (POCAL) arises, representing a revolution in Portuguese municipal accounting, providing better information to responsible for overseeing the financial activities, in different perspectives, as well as allowing continuous monitoring and integrated budgetary and financial management of municipal entities, resulting in greater accountability of their managers and politicians.

The objectives defined by POCAL for municipal accounting, are aligned with the POCP and consist in the "(...) consistent integration of financial, budgetary and cost accounting in a modern public accounting, which constitutes a key instrument to support local authorities" allowing for better monitoring to:

- Support strategic decision making in the context of multi-year budgeting;

- Supporting the activity of monitoring the financial activity of the local administration;

- Increase the transparency of financial position of municipalities;

- Strengthen the use by local authorities of new management techniques;

- Enhancing the transparency of financial relations of municipalities.

Compared with the previous system, based on a public accounting "or traditional cash basis", it focuses exclusively on the provision of responsibilities on the implementation of the budget, not providing information on the cost of services and activities, nor on the assets of the entities. Thus, against this background, the POCAL has the following advantages:

- Greater financial control to allow verification of the legality, regularity and efficiency of financial operations (legal perspective);

- Improve monitoring of budget implementation to determine the budgetary outcomes (budget perspective);

- Enables monitoring and individualized monitoring of the budgetary situation (financial perspective);

- Makes it possible to prepare the balance sheet entities, recognizing the composition and value of their heritage as well as its evolution; 
- Facilitates inventory and control of fixed assets (equity perspective);

- Determines the economic results in analytical terms, showing costs, revenues and results for each good, service or activity (economic perspective and costs);

- Provides timely and relevant information to other organs of the Local Government.

With the implementation of the three required components (budgetary accounting, accrual accounting and cost accounting) was intended to obtain timely, relevant and reliable information that would enable greater transparency in the allocation of public financial resources in order to maximize respective efficiency, effectiveness and economy.

In short, the new system of municipal accounting has been proving to be a great accounting tool, moreover admittedly effective accountability of local authorities, complementing the information on the legal implementation of the budget (cash basis), with information on the financial situation, equity and results of the entity (on an accrual basis), the primary use for decision making.

We reaffirm, thus the statement made earlier in this section relating to the relevance and usefulness of accounting information. It really needs to be reliable and complete requiring the faithful representation of transactions, as well as the interaction between the three elements mentioned.

\subsection{Projected Documents and Provision of Individual Accounts}

Legally, municipalities are in charge of filing various documents and estimates of accountability, as follows:

Table 5. Projected documents and accountability

\begin{tabular}{lll}
\hline \multicolumn{1}{l}{$\begin{array}{l}\text { Maps of financial and economic } \\
\text { information }\end{array}$} & \multicolumn{1}{c}{ Projected Documents } & Balance Sheet \\
Budgetary execution maps & Budget & Income Statement \\
& & Notes to the accounts \\
& PPI-Multiannual & Budgetary control of expenditure \\
Investment Plan & Budgetary control revenue \\
Reports & Map of Cash Flows \\
Other documents & Attachments to budgetary reporting \\
& Annual execution of PPI \\
& Management Report \\
& Minutes to approve accounts \\
& Internal Control Standard and its \\
& amendments \\
& Summary of Daily Treasury \\
& Summary of Bank reconciliations \\
& Maps of Funds Working Capital \\
& Accounts of each Municipal Service and \\
& Municipal Company \\
& Social balance \\
&
\end{tabular}

Source: Adapted: Carvalho et al (2009:35) AFMP

\subsection{Multi-Year Investment Plan (PPI)}

At this point, we discuss the map that presents the implementation of the Multiannual Investment Plan, which provides information on the financial implementation of projects, reported on December 31 of each year. The PPI should be organized and structured by objectives, programs, projects, and eventually actions. It developed a mobile base of 4 years. For example, the PPI designed in 2010 corresponds to the four-year period 2010/2013 and reflects the consumption of financial projects started in 2010, with financial and treasury repercussions that 
year or subsequent years. It also reflects monetary outlay projects initiated in previous years but whose economic material and / or financial juts in 2010 or even beyond implementation date. With this information you can determine the projects / actions that are completed in the financial year under review and which continue in the following years as well as what is the total amount spent on each project / action already initiated or to start, in this case, 2010.

\subsection{Informations of Municipalities Assets}

The POCAL as well as Resolution No. 1/2004 of the Court of Auditors, include in the accounts to be submitted by municipalities, property and economic information very similar to that presented by companies in the private business sector and public sector. The Balance Sheet, the Income Statement Map and the notes of accounts and its annexes are a common practice. These documents are drawn on an accrual basis or accrual accounting, while the budgetary information is prepared on a cash basis or commitments and rights.

The following table shows, for the financial years 2006/2010, a summary of the information produced by local authorities in respect of accountability:

Table 6. Information and economic equity of portuguese municipalities

\begin{tabular}{|c|c|c|c|c|c|}
\hline & 2006 & 2007 & 2008 & 2009 & 2010 \\
\hline Existing municipalities in Portugal & 308 & 308 & 308 & 308 & 308 \\
\hline Analyzed municipalities & 308 & 308 & 308 & 308 & 308 \\
\hline $\begin{array}{l}\text { Present the Balance Sheet and Income statement at the } \\
\text { accountability }\end{array}$ & 308 & 308 & 308 & 308 & 308 \\
\hline Include depreciation on the Map of Income Statement & 293 & 295 & 299 & 303 & 304 \\
\hline Have in the asset Public heritage but have no value in land & 89 & 77 & 71 & 63 & 53 \\
\hline $\begin{array}{l}\text { Have in the asset Public heritage but have no value at artistic } \\
\text { history and cultural heritage }\end{array}$ & 142 & 152 & 166 & 171 & 176 \\
\hline The asset presents the amounts on public heritage & 302 & 306 & 308 & 308 & 308 \\
\hline The public heritage are higher than $20 \%$ of Assets & 247 & 257 & 267 & 270 & 268 \\
\hline Reported deferred income on the balance sheet (liabilities) & 281 & 289 & 293 & 297 & 298 \\
\hline $\begin{array}{l}\text { Have receivables from customers, taxpayers and users in the } \\
\text { balance sheet }\end{array}$ & 303 & 306 & 290 & 289 & 290 \\
\hline Present values of stocks in the balance sheet & 200 & 215 & 235 & 245 & 259 \\
\hline Have provisions for the year in the Map of Income Statement & 92 & 127 & 143 & 155 & 165 \\
\hline Presented deferred costs in the balance sheet & 221 & 251 & 269 & 276 & 289 \\
\hline
\end{tabular}

Source: Adapted: Carvalho et al (2010:94) AFMP

Analysis of the above table, with information including a summary on compliance with the standards listed in POCAL, regarding the accrual accounting system, allows us to verify that there are some situations in which there is full compliance by the Municipalities of obligations imposed by the rules of accrual accounting. However, the national territorial space, all presented in 2009 and the Balance Sheet Income Statement as accountability documents, a situation which indeed is already happening since 2006. Accordingly, the reliability of equity and economic information is not presented in its entirety, although a positive trend observed over the years under review.

The account "25 - Debtors and Creditors for Budget Execution" is an account that makes the connection between budgetary accounting and accrual accounting and must be busting whenever there are financial inflows and outflows of funds from institutions, either by implementing the budget whether as a result of treasury operations. Thus, this account is as essential as the intersection of accounting information at the level of cash flows and the related phenomenon of settlement in the case of expenditure or revenue accounts through the third element. This act gives a financial accounting procedure for recording with simultaneous impact on accrual accounting, the accounts of others. 
Keeping in mind we focus mainly on control mechanisms for compliance and reliability of information provided by outputs extracted from this linkage, it will be essential for a methodological point of view, to establish a form of verification of conformity between the information provided and performed more precisely between the estimates documents and documents of accountability. The documents of accountability should be the mirror of the estimates documents, once approved the foundation for the development of financial activity.

\section{Empirical Study of Municipalities of Central Region - NUTs 2001}

Local Authorities in the performance evaluation is scheduled in various legal documents and has been performed by several researchers, as regards (Carvalho et al, 2010:213).

"(...) Sometimes with a set of selected to assess the financial, economic, equity and financial management of municipalities indicators, fulfilling other criteria of efficiency, economy and effectiveness, and others, evaluating the effectiveness, efficiency and quality, through the Framework Assessment and Accountability (QUAR), in compliance with that recommended in the Performance Evaluation System of Public Administration Services (SIAPAD 1).

The Statistics Central Region of Portugal is a Territorial Unit for Statistics Level II (NUTS II) of Portugal, and fully occupies the districts of Coimbra, Leiria and Castelo Branco, most districts of Viseu, Aveiro and Guarda and about a third of the district of Santarém. Bounded on the north by the North Region, east to Spain, with the southern Alentejo, south west with the Lisbon Region and west to the Atlantic Ocean.

In this context, the objective of this study aims to highlight the level of Municipalities this statistical region on the one hand the different perspectives of evaluating their performance, supported by financial information generated by various supporting reports and, secondly, the possibility of comparability of that performance evaluation from indicators to be disclosed in the management report. The development of the subject will be made from the Annual Financial Report of Portuguese Municipalities (AFMP) of QUAR, the Management Report and focusing more on analyzing the questions put to respondents through a survey sent to municipalities.

There are many limitations, conflicting interests, uncertainties, paradoxes and ambivalences, which make performance measurement a complicated undertaking. There is some ambiguity and disagreement about what users should do with the measurement of this indicator and unintended use of performance measurement information. To others have more severe measures, issues that can make the ideas of cultures, result oriented management unsustainable.

According to the opinion of (Lapsley, 1999), New Public Management (NPM) has been considered by some authors as having failed in terms of results "(...) this has been a bitter disappointment to the makers and users."

Performance measurement is more important in large organizations because managing larger budgets and because they have more extensive resources. Institutional bodies try to guide and promote these changes, with the introduction of new techniques of performance management, such as accounting management, reflected in total quality management systems and environmental management systems, which have been recommended.

Regarding the use of performance measures, there are still some doubts as to whether they are actually used in decision-making process, or if governments do have better management and accountability.

\subsection{Performance Information}

We based our study on a questionnaire sent to the managers of local governments that constitute the Statistics Central Region of Portugal NUTS 2001.

It is our goal to which the techniques used in performance management, that somehow reflect the relevance applied by these local entities, given the quality of service that is provided to residents, as well as how to evaluate the perception of managers on the usefulness these new analytical tools necessary for the use of best management practices used by local governments in Portugal.

Using the data from this survey, we look at the key variables that influence best practices in performance management and usefulness of new tools for decision support.

\subsection{Sample Characterization}

Noticed by the literature review, the public accounting tends to undergo changes over time, incidentally, accompanying the changes observed in the private business sector. Accordingly, we performed an empirical study to public institutions, here called by Local Governments that use POCAL.

This study was conducted through a questionnaire sent by email and took into account the points listed then online. 


\subsection{Methodology}

The choice and definition of a research methodology is critical in determining the approach to the object of study, namely establishing the methods that should be used in the analysis of a given phenomenon, considering a pre-defined goal. The study object (target population) of this dissertation is the Local Authorities within the perimeter of the central region in the analysis.

In this sense, we believe it is important to have a brief characterization of the study.

\subsection{General Considerations}

In the course of the literature review, we became aware that over the years there have been several steps towards harmonization of accounting in the public sector, so, being more a reform of certain underlying order for this sector, it seemed appropriate to pursue through a survey, collect opinions from third parties related directly or indirectly to the subject of standards and know with the financial responsibility of these local government bodies, whether they are ready or not for a reform of this kind, particularly if financial value indicators, performance and budgetary, which we believe are the cornerstones of this change.

To concretize our claim, we begin by drawing up a set questionnaire in order to collect data and opinions backed people, related to the financial services and support to the management of municipalities.

\subsection{Objectives}

In designing the questionnaire had in mind the financial area of public accounting line, notably represented by the heads of departments and services.

So we had the specific objectives intended to meet:

1) If all Authorities now use POCAL in its entirety, i.e., if all three are fully consolidated accounting aspects;

2) What types of knowledge are the financial responsibility of these public institutions, regarding the accounting standards of the private sector, and consider important to a future change in the public sector;

3) The importance of a conceptual framework that addresses, among other things, concepts like assets, liabilities, appropriateness, commitment;

4) What accounting principles respondents consider that they should continue to exist;

5) The accounting documents with greater utility for internal and external users of financial public information.

\subsection{Definition and Characterization of Population}

With regard to the chosen population (Vergara 2004) discloses

"(...) Population is in a set of elements (companies, products, people) that have the necessary characteristics to the object of study. With regard to the population of the sample, it can be understood that it is part of the chosen population according to a representative criterion".

Accordingly, a questionnaire to the responsible Local Government Financial Statistics of the Region was sent on study, public institutions already working with POCAL.

The questionnaire was structured in the same way for the whole target population.

\subsection{Development and Application of the Questionnaire}

The questionnaire was developed in EXCEL computer readable file sent to the email address of respondents, along with a letter addressed to the Presidents of Municipalities. Regarding the type of questions, it was decided to closed questions and multiple choice. To have a wider range of responses, we applied some open questions, such as "Another, What? Why?" In order to obtain qualitative information to complement and contextualize the quantitative information obtained by other variables.

Were even made matters simple answer that would allow closed questions, e.g. "Yes, No, None, Some and Much".

Regarding the type of scales, we used verbal scales with ordering (called Likert scales, which can measure levels of disagreement / agreement, the usefulness and importance (e.g. 1 - None; 2 - Something, 3 - Somewhat; Very 4, 5 - completely). 
The questionnaire prepared - "Questionnaire Research Municipalities", is structured in two parts. The first related to the characterization of the respondent and the second which includes the generic issues in order to meet the objectives established by us.

The early submission of the questionnaire took place during the month of April 2012, 78 questionnaires were sent. To this submission attempt, given that the number of responses was not satisfactory, followed by several parcels of reminders and phone calls to the right of the months of May and June, those responsible for the financial departments of all Authorities involved, for collaboration more in this study.

In total we managed to get 44 response which amounts to approximately $56.4 \%$ of the responses. (44 is the sample of the target population 78).

\subsection{Analysis of Results}

As mentioned in 3.6, the survey was aimed at financial officers of local authorities. We spent analyzing the results, given the various issues raised.

\subsubsection{Sample Definition}

78 questionnaires were sent, several attempts to obtain answers to those in charge of the finance departments of all Authorities involved have been developed. In total 44 responses were obtained, which amounts to approximately $56.4 \%$ of total responses.

Questions were posed to the respondents, including on the "modus operandi" of the Financial Department of the institution where they play roles and to which we obtained $56.4 \%$ of validated responses.

Table 7. Municipalities respondents to the survey, by districts NUTS II central region

\begin{tabular}{lccc}
\hline Local governments by District & $\begin{array}{c}\text { Number of } \\
\text { respondents }\end{array}$ & \% of answers & \% Not answered \\
\hline Aveiro & 7 & 5 \\
Castelo Branco & 6 & 5 \\
Coimbra & 11 & 6 \\
Guarda & 5 & 8 \\
Leiria & 6 & 4 \\
Santarém (Município de Mação) & 1 & 0 \\
Viseu & 8 & 6 \\
Total & $\mathbf{4 4}$ & $\mathbf{0 , 5 6 4}$ & $\mathbf{0 , 4 3 6}$ \\
\hline
\end{tabular}

Source: own making

As we can see from the previous table, those who adhered more to this study were the Municipalities of the district of Coimbra. 


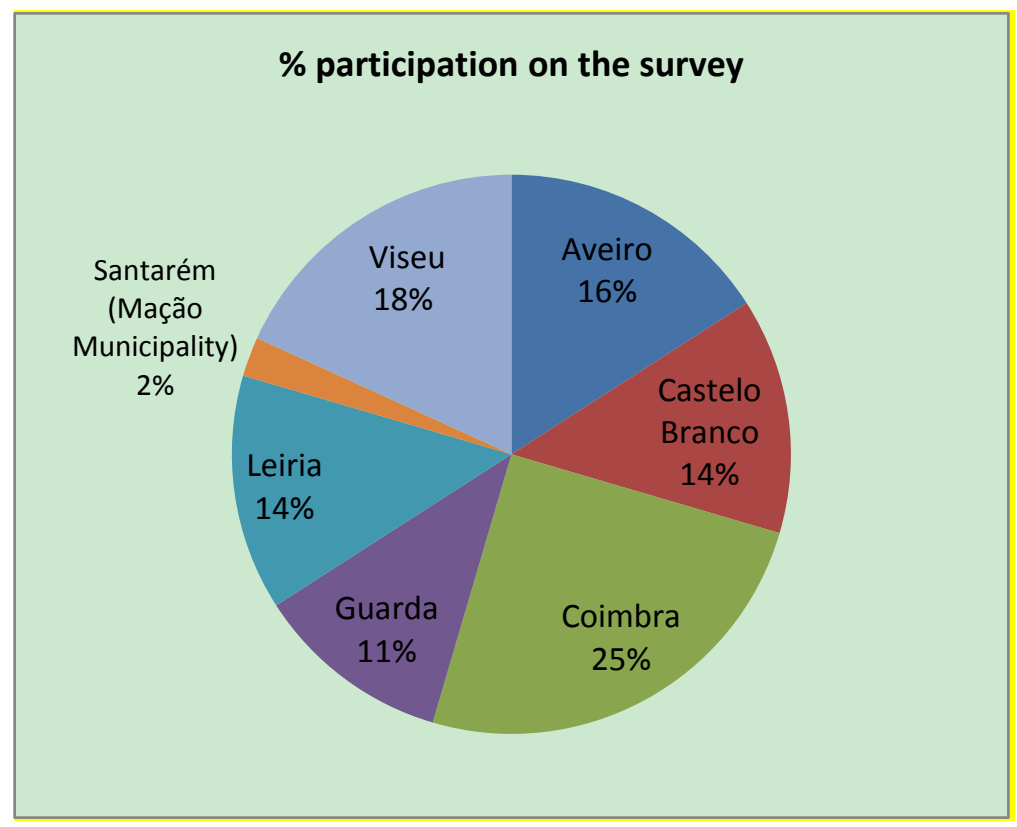

Figure 2. Percentage of participation survey

\section{Research Results}

\subsection{Financial Independence of Municipalities}

To check the degree of financial independence of local authorities, we adopt the ratio that relates the own revenues to total revenues. Whereas there will be financial independence (Note 3) when own revenues (Note 4) represent at least $50 \%$ of total revenues.

Following the reasoning of the authors of the AFMP, and to better understand the evolution of this indicator, so we compared for the years 2008 and 2009 by groups of municipalities, the weights of own revenue, transfers and financial liabilities, total revenue.

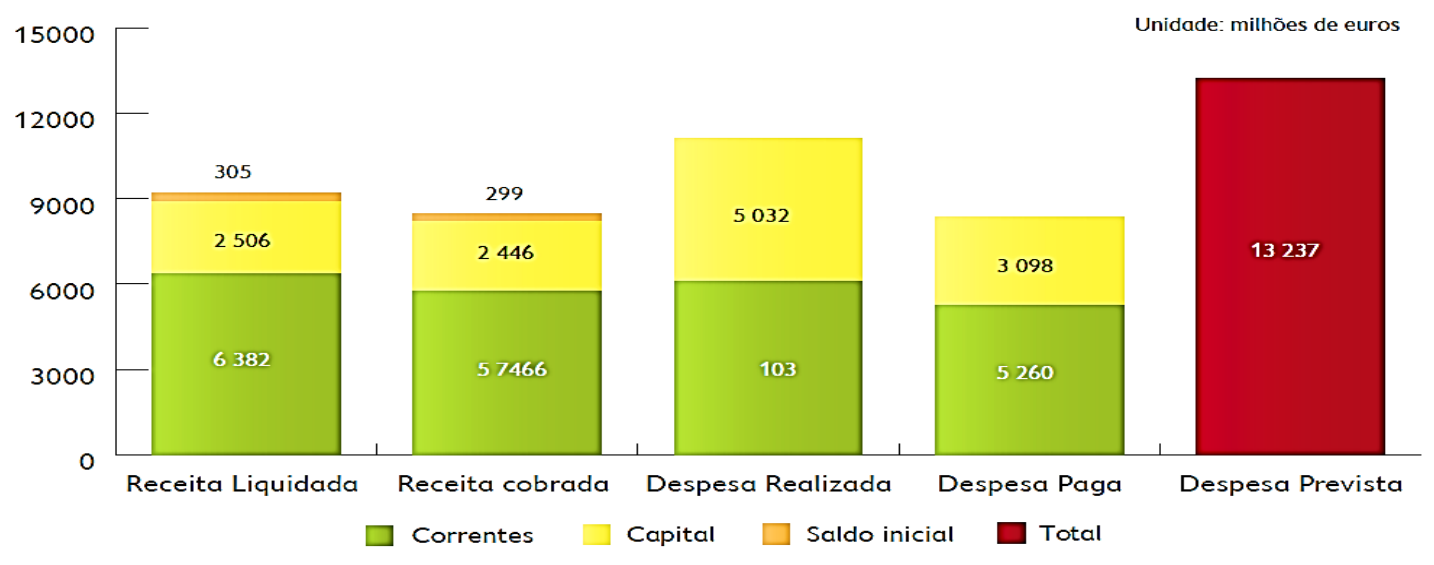

Figure 3. Structure of revenue and expense paid and realized

Source: Adapted Carvalho et al (2009:53)

The joint observation of the figures 3 and 4, we can conclude that financial independence is higher in large cities, representing on average in 2009 , own revenues $64 \%$ of total revenues of the respective municipalities. 


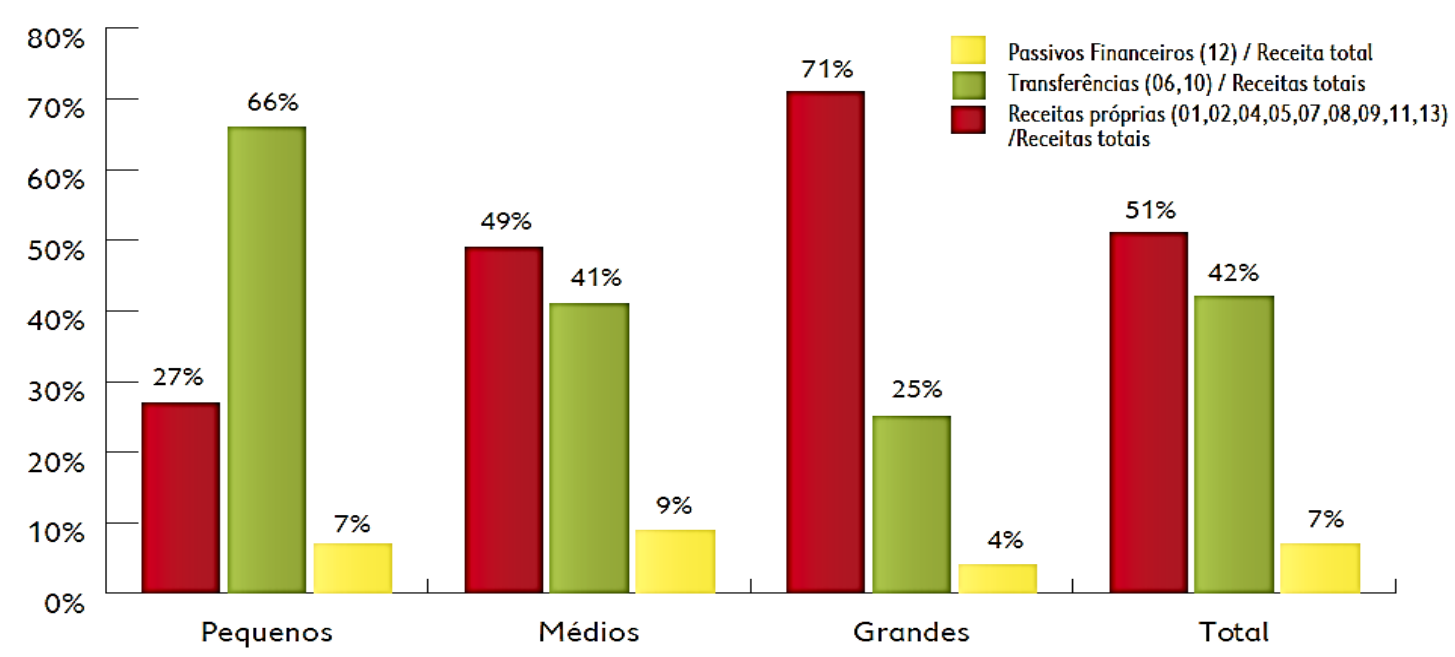

Figure 4. Financial structure of municipalities (2008)

Source: Adapted Carvalho et al (2009:53) AFMP

We also verified that the small municipalities in financial terms depend more on transfers received by FEF (Note 5 ), representing on average in the year under study, $64 \%$ of total revenues. Own resources account for only $23 \%$ of total revenues, by translating a very low financial independence.

For medium-sized municipalities, the state transfers and own revenues, contribute almost equally, between the two balancing their financial capacity.

This study compares the two previous charts and verifies that the total universe of municipalities, the value of financial independence ratio fell 6 percentage points from 2008 to 2009 , from $51 \%$ to $45 \%$, respectively. This decline was most pronounced at the level of municipalities large $(-7 \%)$ and less significant for municipalities average $(-5 \%)$ and small $(-4 \%)$ dimension. The weight of the use of credit (financial liabilities) to total revenues, the ratio was more evolved, from 2008 to 2009 . On average, this indicator increased by $5 \%$, getting close to doubling this value, compared with the year 2008. Relatively large municipalities, this indicator increased from $4 \%$ to $9 \%$. In small municipalities evolution increased from $7 \%$ to $13 \%$. Analyzing the evolution of the ratio Financial Independence in four years 2006/2009, (Figure 3) it is found that it showed a progressive decrease in 2007 and 2008, the municipalities of small and large scale, leading to a sharp decline in 2009. The same phenomenon had been already verified for medium-sized municipalities from 2008.

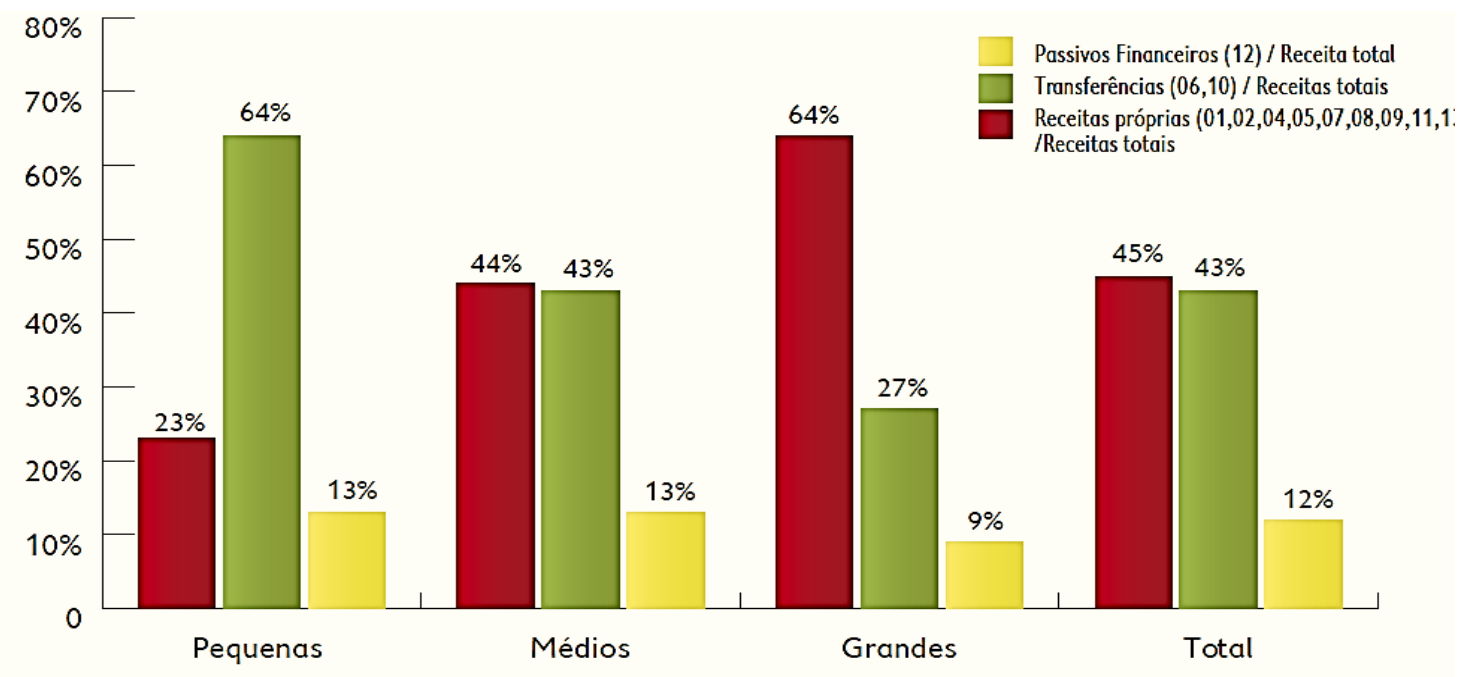

Figure 5. Financial structure of municipalities (2009)

Source: Adapted Carvalho et al (2009:53) 


\section{2 Results}

In terms of synthesis results we can say that all municipalities use double entry accounting. Accountable to officials, presenting the budgetary implementation, the balance sheet, the income statement and the additional information required.

All local authorities as relevant to include in their financial reporting, performance indicators, economic indicators and fiscal indicators, even if they are intended only for internal purposes. As more important indicators they consider the economy, efficiency, effectiveness and sustainability.

Only 39\% of municipalities' respondents present consolidated accounts, which also deliver to the officials mentioned above, especially the Court of Auditors, the General Directorate of Local Authorities, General Directorate of Budget (DGO) and Office of National Statistics (INE). $77 \%$ of the Boards give importance to the consolidated accounts. 38 municipalities consider important to include, financial, economic, budgetary and performance indicators in financial reporting for external purposes.

15 Local Authorities consider the indicator "municipal indebtedness" as most important, followed by "expenditure execution" with 12 and 5 with immediate liquidity.

In response to the question "What is the most difficult phase to treat public assets?" $64 \%$ answered that it was the inventory, $27 \%$ evaluation, classification $7 \%$ and $2 \%$ responded blank. As relates to the importance that financial information produced with the support of key performance indicators, economic, financial and fiscal, external reach to the users, especially to householders, 26 municipalities consider important, very important 14,1 fully considered, 1 indifferent and 2 responded blank.

About whether the financial statements and the consolidated accounts are analyzed by internal and / or auditors audited by a Chartered Accountant, 32 positive responses, 10 negative and 2 were obtained in white.

Were asked to rate the recipients of accounting information in order of importance, about public assets (1 - most important, 6 - least important) and 31 municipalities considered the entity itself, 4 considers the General Directorate of Local Authorities, 2 consider the citizens, 1 others and 1 considers the INE.

The degree of knowledge they have about the accounting reform in the private sector (SNC) in 2009, 48\% said having reasonable knowledge of the reform, $25 \%$ know anything about it, $18 \%$ did not know anything and $2 \%$ too. The others have not responded. About this reform, 36 municipalities consider an identical advantageous in local public sector reform, 6 do not consider important and the rest do not respond.

Were still allowed open answers on this subject, and was generally advocated a rapprochement between the public and private sector as it relates to the accounting system adopted.

\subsection{Revenues of Municipalities}

Table 8. Revenues of municipalities 2012/2013 (Unit: millions of euros)

\begin{tabular}{|c|c|c|c|}
\hline Municipalities & 2013 & 2012 & $\Delta$ 2012-2013 \\
\hline Total Revenues & $7.774,80$ & $7.683,40$ & 91,40 \\
\hline Revenues of the State Budget & $2.284,23$ & $2.284,00$ & 0,23 \\
\hline
\end{tabular}

Source: own making

The data in Table 8 shows that there was a positive development of revenue collected in the years 2012 and 2013 . However, according to the Annual Financial Report of Municipalities of the year 2013, the change in revenue collected for the years 2009/2010, 2010/2011 and 2011/2012 was $-4.1 \%,-1.1 \%$ and $-1.1 \%$, respectively.

This may be due firstly to the tighter measures of tax administration and the other to a better financial and accounting procedures arising from the requirements of national and international authorities.

\section{Conclusions}

The public accounting to produce financial information for decision support in real time plays a crucial and highly relevant role in the control and management of public resources. It is a tool to ensure, through the use of various tools and control mechanisms, legality, economy, efficiency and effectiveness of public spending and the clarity and transparency in the management of public funds and financial relations of the State.

The accounting information, in close connection with the performance information, should serve as a basis for 
decisions, basing them before potential users, both internally and externally.

In terms of local government, public accounting has evolved over time and, when combined with other sources of non-financial information, has proven a great tool to support management and consequent decision.

Economic globalization and the global financial crisis that followed worsened further, the scarce available under the jurisdictions of the municipalities resources, creating a need for control of net debt, now taken to the limits with the approval of the new law commitments and arrears (LCPA). By framing this Act within the local governments, the state will require to place greater budgetary transparency, not allowing inflating revenues and consequent budgetary false expectations on the expenditure side. Budgets tend to call "zero base" and bind the fundamental choices in the opportunity cost incurred.

All this will take charge of municipalities, the tight controls in its management. However, the use of best practices, will allow them to produce information for financial reports, making them more reliable and comparable.

Through the knowledge gained from conducting this investigation, we find that to good management and decision support, sustaining nature of measures supported on best practices, supported by credible financial information, which can provide POCAL have to be taken. In addition to the financial information contained in the reports produced by service and, with the support of the various branches of accounting, another aspect of non-financial information, it has been prove quite fruitful.

Results of this study enough knowledge to opine on these public entities, claiming they had played in the recent past, a decisive role in the development of basic infrastructure in the territories under the administrative jurisdiction of the respective municipalities and populations locally represent.

The final comments of the financial officers of local authorities, in answer to twenty and seven of questionnaire, is indicative of the interest in the evolution of municipal accounting and her approach to the private sector.

We had some limitations, claiming financial responsibility lack of time to receive us, motivated by readjusting the debt, given the commitments of the new law and the delivery of reporting and accountability.

Furthermore, noted here that the issue of consolidation of accounts between municipalities and other local entities has become even more specific from January 2010, with the entry into force for the private sector, the new Accounting Standards System (SNC).

Indeed, from 2010 all entities of the local business sector began to implement the SNC, continuing municipalities and municipal services using POCAL.

Accordingly, and as part of a possible reform of public accounting, the amendment to POCAL planned and expected, will have to contemplate the new regulatory framework SNC. This alone demonstrates the need to take action to adapt to POCAL International Standard Public Sector Accounting Standards (IPSAS).

\section{References}

AECA - Asociacion Española de Contabilidad y Administracion de Empresas. (2003). Princípios de Organizacion y Sistemas (Doc. 23) - Contabilidad de las entidades sim Fines de Lucrativos, Madrid, España.

Almeida, J. M. (2000). Avaliação e Controlo nas Organizações, Revista de Contabilidade e Comércio, 226-Vol. LVII, pp. 285-305.

Barbosa da Silva, A. (1994). Management Público - Reforma da Administração Financeira do Estado. Rei dos Livros. Lisboa.

Barbosa da Silva, A. (1994). Management Público - Uma abordagem micro-orçamental. INA, Oeiras.

Bilhim, J. (2004). A Governação nas Autarquias Locais- Editora SPI-Porto.

Brignall, S., \& Modell, S. (2000). An institutional perspective on performance measurement and management in the new public sector. Management Accounting Research, 11, 281-306. http://dx.doi.org/10.1006/mare.2000.0136

Caiado, P., Carvalho, J., \& Silveira, O. (2006). Contabilidade Pública: Legislação. Áreas Editora. Lisboa.

Camões, P., Jorge, S., Carvalho, J., \& Fernandes, M. J. (2008). Does Accounting Compliance Improve Financial Performance? An Econometric analysis of Portuguese Local Government. European Group of Public Administration (EGPA) Conference, Rotterdam, Netherlands, 3-6 Setembro. 
Carvalho, J. (2009). Os Municípios Portugueses: análise financeira e cumprimento da Lei das Finanças Locais. Revista de Direito Regional e Local 6 Abril/Junho, pp. 17-26.

Carvalho, J. et al. (2009). Determinantes da Adoção e Desenvolvimento do Sistema de Contabilidade de Custos nos Municípios Portugueses.

Carvalho, J., Fernandes, M. J., Camões, P., \& Jorge, S. (Eds.). (2009). Anuário Financeiro dos Municípios Portugueses - 2007. Lisboa: Câmara dos Técnicos Oficiais de Contas (CTOC).

Carvalho, João M. S. (2005). Organizações Não Lucrativas, Edições Sílabo, Lisboa, Portugal.

Constituição da República Portuguesa (CRP) 1976.

Hood, C. (1995). The new public management in the 1980s: variations on a theme. Accounting, Organizations and Society, 20, 93-109. http://dx.doi.org/10.1016/0361-3682(93)E0001-W

Jackson, A., \& Lapsley, I. (2003). The diffusion of accounting practices in the new "managerial" public sector. Journal of Public Sector Management, 16(5), 359-372. http://dx.doi.org/10.1108/09513550310489304

Lakatos, E. M., \& Marconi, M. A. (1986). Técnicas de pesquisa: planejamento e execução de pesquisas, amostragens e técnicas de pesquisa, elaboração, análise e interpretação de dados. São Paulo: Atlas.

Lapsley, I. (1999). Accounting and The New Public Management: Instruments of substantive efficiency or a rationalising modernity? Financial Accountability \& Management, 15(3/4), 201-207. http://dx.doi.org/10.1111/1468-0408.00081

OTOC. (2011). Anuário Financeiro dos Municípios Portugueses 2009. Edição: Ordem dos Técnicos Oficiais de Contas, fevereiro 2011.

OTOC. (2012). Anuário Financeiro dos Municípios Portugueses 2010; Edição: Ordem dos Técnicos Oficiais de Contas, abril de 2012.

OTOC. (2014). Anuário Financeiro dos Municípios Portugueses 2013; Edição: Ordem dos Técnicos Oficiais de Contas, abril de 2014.

Reck, J. (2001). The Usefulness of Financial and Nonfinancial Performance Information in Resource Allocation Decisions. Journal of Accounting and Public Policy, 20(1), 45-71. http://dx.doi.org/10.1016/S0278-4254(01)00018-7

Vergara, S. C. (2004). Projetos e relatórios de pesquisa em Administração. São Paulo: Atlas.

\section{Legislation}

Law n. ${ }^{\circ} 8 / 1990$, February 20. Law on Public Accounts.

Decree-Law n. ${ }^{\circ}$ 155/1992 July 28. Regulation of the Law on Public Accounts.

Decree-Law no $54-A / 1999$, February 22. Official Accounting Plan of Local Authorities (POCAL).

Law $n^{\circ} 2 / 2007$, January 15 . Local Finance Law (NLFL).

Decree-Law n. ${ }^{\circ}$ 158/2009, July 13 - approving the SNC Accounting Standards System and comes into force on January 1, 2010.

\section{Notes}

Note 1. Given the criteria of reference subsectors considered in the General State Account, the figures for the central government subsector does not include the value of Social Security and Local Government has included the value of the regional administration.

Note 2. Changes made to this law through:

- Law No. 162/99 of September 14 (art. 5 changes, 9. ${ }^{\circ}, 10^{\circ}, 11^{\circ}$ and 12. Decree Law No. 54-A/99 of 22 February)

- Decree-Law No. 315/2000, dated December 2 (amendment to Article 10. ${ }^{\circ}$ and 12 of Decree Law No. 54-A/99, February 22) Decree-Law No. 84-A/22002, April 5 (amendment of POCAL, point No. 3.3 Estimated Rules).

Note 3. Concept that can't be confused with the Financial Autonomy, as referred to in Article 3. of the Local 
Finance Law.

Note 4. The AFMP considers, for this purpose, that municipality's own revenues are total revenues net of transfers and financial liabilities.

Note 5. FEF - Financial balance fund.

\section{Copyrights}

Copyright for this article is retained by the author(s), with first publication rights granted to the journal.

This is an open-access article distributed under the terms and conditions of the Creative Commons Attribution license (http://creativecommons.org/licenses/by/3.0/). 